\title{
PSEUDOCHOLINESTERASE AS A PREDICTOR MARKER IN HYPOTHYROID PATIENTS
}

\author{
Kaushik GG ${ }^{1}$, Soni Reena ${ }^{2}$ \\ ${ }^{1}$ Sr.Professor \& HOD, ${ }^{2}$ Resident, Department of Biochemistry, \\ J.L.N. Medical College, Ajmer, Rajasthan, India.
}

\section{ABSTRACT}

Introduction: Hypothyroidism is due to decreased circulating levels of Thyroid hormones and is caused by inadequate functioning of thyroid gland. Pseudocholinesterase (PCHE) is a nonspecific cholinesterase enzyme that hydrolyses choline based esters in plasma. The purpose of this study was to evaluate the serum level of PCHE in hypothyroid patients. Methodology: The present study was conducted on 100 newly diagnosed hypothyroid patients attending the Medical OPD. The results of patients were compared with 100 healthy controls of either sex of similar age group. Anthropometric measurements, T3, T4, TSH, PCHE \& Cholesterol estimations were performed. Results: The mean serum PCHE (decrease) level was observed statistically highly significant $(p<0.001)$ in hypothyroid patients as compared with healthy control subjects. A highly significant positive correlation between PCHE with T3 \& T4 ( $p<$ 0.001 ) in hypothyroid cases. Conclusion: Serum Pseudocholinesterase may be helpful as biomarker in screening test for hypothyroidism along with thyroid stimulating hormone.

KEYWORDS: Hypothyroidism; Thyroid Profile; Pseudocholinesterase.

\section{INTRODUCTION}

Hypothyroidism is one of the common occurrence of endocrine disorders in India [1]. Hypothyroidism is a clinical event resulting from the deficiency of thyroid hormones or rarely from their impaired activity at the tissue level. Cholinesterase represents a group of enzymes that hydrolyze acetylcholine and other choline esters. There are two main types of cholinesterase with different biochemical properties: true or specific cholinesterase or acetyl cholinesterase found in all excitable tissues (central and peripheral nervous system and muscles) and in erythrocytes. It is a high-turnover enzyme with high affinity for acetylcholine, inhibited at high concentrations of acetylcholine, and with low affinity for non-cholineesters. The other one is the nonspecific or pseudocholinesterase or butyrylcholinesterase which hydrolyses both choline and aliphatic esters. $\mathrm{PCHE}$ is a $\alpha$ glycoprotein found in the central and peripheral nervous system, in most tissues, and in the liver [2]. PCHE is synthesized in liver and its serum activity is influenced by liver disease. PCHE level in serum is a useful test of liver function [3]. Patients with myxoedema, the pathologically increased levels of serum

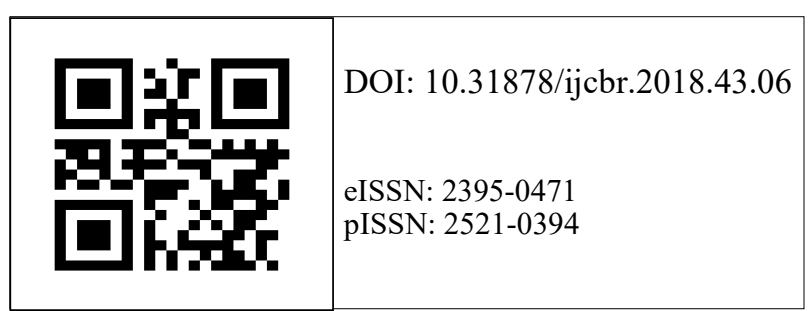

cholesterol (TC) and beta-lipoproteins were associated with diminished serum PCHE activity. The percentage of the pre-beta fraction was found to be increased in both hypo - and hyperthyroid patients, but mechanisms leading to this change are probably different in the two pathological conditions. The behaviour of TC and PCHE activity and especially the ratio between these parameters might be used for the diagnosis of thyroid disease and for the control of therapeutic efficiency [4]. The purpose of this study was to evaluate the serum level of PCHE in hypothyroid patients.

\section{MATERIALS AND METHODS}

Study design: Case control observational study.

Ethics approval: Ethics approval by obtained from our institute JLN Medical College, Ajmer and informed consent was taken from the participants.

Study location: Patients attending the Medical OPD and Laboratory of the Biochemistry Department of JLN Medical College \& Hospitals, Ajmer.

Study period: $2015-2018$.

Sample size: 200 volunteers participated (Case $=100$, Control =100).

Sampling method: Consecutive sampling method was used.

Correspondence: Soni Reena, Resident, Department of Biochemistry, J.L.N. Medical College, Ajmer, Rajasthan, India. Email: nagrajsoni3@gmail.com 
Inclusion criteria: The present study was conducted on 100 newly diagnosed hypothyroid patients. The diagnose of hypothyroidism was established, based on the clinical signs and symptoms and the T3, T4 and TSH estimations (American Thyroid Association). For control group age and sex matched healthy volunteers were selected.

Exclusion criteria: Patients on treatment for any thyroid disorder, liver disease, lipid lowering drugs, diabetes, malignancy and pregnant women were excluded.

Grouping: Group 1: Hypothyroid Group 2 : Control

Methodology: From every participant questionnaire was given to find out the relevant information. Anthropometric assessment was done and BMI was calculated [6]. Blood pressure was measured after 10 minutes of rest as routine examination. $3 \mathrm{ml}$ of blood sample was collected aseptically, serum was separated and used for estimation of thyroid profile [7-9] and Pseudocholinesterase [10] were done by using a ELISA method and serum cholesterol was done by enzymatic CHODPOD, end point method [11].

Statistical analysis: Data (parameters) were presented as mean \pm standard deviation. Level of statistical significance was set at $p<0.05$.

\section{RESULTS}

Table 1. Comparison of thyroid parameters \& PCHE in both study groups.

\begin{tabular}{|l|l|l|l|}
\hline $\begin{array}{l}\text { Parame- } \\
\text { ters }\end{array}$ & $\begin{array}{l}\text { Healthy } \\
\text { Controls } \\
\text { (Mean } \\
\pm \text { S.D.) }\end{array}$ & $\begin{array}{l}\text { Hypothyroid } \\
\text { Patients } \\
\text { (Mean } \pm \text { S.D.) }\end{array}$ & $\begin{array}{l}\text { p- } \\
\text { value }\end{array}$ \\
\hline $\begin{array}{l}\text { Total T3 } \\
(\mathrm{ng} / \mathrm{ml})\end{array}$ & $1.15 \pm 0.36$ & $0.41 \pm 0.20$ & $\begin{array}{l}0.0001 \\
* *\end{array}$ \\
\hline $\begin{array}{l}\text { Total T4 } \\
(\mu \mathrm{g} / \mathrm{dl})\end{array}$ & $7.63 \pm 1.59$ & $2.67 \pm 1.25$ & $\begin{array}{l}0.0001 \\
* *\end{array}$ \\
\hline $\begin{array}{l}\mathrm{TSH} \\
(\mu \mathrm{lU} / \mathrm{ml})\end{array}$ & $2.91 \pm 1.25$ & $31.01 \pm 8.18$ & $\begin{array}{l}0.0001 \\
* *\end{array}$ \\
\hline $\mathrm{PCHE} \mathrm{(U/L)}$ & $\begin{array}{l}6760.21 \pm 94 \\
4.82\end{array}$ & $3180.10 \pm 707.86$ & $\begin{array}{l}0.001 * \\
*\end{array}$ \\
\hline $\mathrm{TC}(\mathrm{mg} / \mathrm{dl})$ & $\begin{array}{l}188.70 \pm 12.2 \\
9\end{array}$ & $250.74 \pm 16.66$ & $\begin{array}{l}0.0001 \\
* *\end{array}$ \\
\hline
\end{tabular}

Note: $\quad p>0.05=$ Not significant (NS); $* p<0.05=$ Significant; ${ }^{* *} \mathrm{p}<0.001=$ Highly significant (HS).

Table 2. Pearson correlation of PCHE (U/ml) with thyroid parameters.

\begin{tabular}{|l|l|l|}
\hline \multicolumn{3}{|l|}{ Hypothyroid Patients } \\
\hline Parameters & $\begin{array}{l}\text { Pearson } \\
\text { correlation ( } r \text { ) }\end{array}$ & P- Value \\
\hline PCHE vs T3 & 0.1973 & $\mathrm{p}<0.001$ \\
\hline PCHE vs T4 & 0.0217 & $\mathrm{p}<0.001$ \\
\hline PCHE vs TSH & -0.1302 & 0.095 \\
\hline
\end{tabular}

The Mean \pm SD levels of T3, T4 and PCHE were lower in hypothyroid patients, even with elevated serum TSH \& cholesterol levels as compared to controls. Serum thyroid profile. TC and PCHE were observed statistically highly significant $\left(p<0.0001^{* *}\right)$ in hypothyroid patients when compared with euthyroid subjects (Table 1 ). Table :2 shows a highly significant positive correlation between PCHE with total T3 \& T4 $(p<0.001)$ in hypothyroid cases. The correlation between PCHE and TSH is negative. Due to decrease in T4 levels there is increase in TSH secretion in hypothyroid cases.

\section{DISCUSSION}

Hypothyroidism is a condition characterized by abnormally low thyroid hormone production. There are many disorders that result in hypothyroidism. These disorders may directly or indirectly involve the thyroid gland. Because thyroid hormone affects growth, development, and many cellular processes, inadequate thyroid hormone has widespread consequences for the body. The results of the present study were found similar to Sleeba S K et [5], Thompson J.C et al [12] and Vlaicu $R$ et al [4]. Vlaicu $R$ et al [4]showed that decreased levels of Serum cholesterol and betalipoproteins occurring in hyperthyroidism were found to be accompanied by an enhanced activity of pseudocholinesterase, while in patients with myxedema, the pathologically increased levels of serum cholesterol and beta-lipoproteins were associated with diminished serum pseudocholinesterase activity. The behaviour of cholesterol and pseudocholinesterase activity and especially the ratio between these parameters might be used for the diagnosis of thyroid disease and for the control of therapeutic efficiency. In the present study we estimated pseudocholinesterase as diagnostic and prognostic marker for hypothyroid cases. Pseudocholinesterase was found to be a diagnostic marker in detecting new cases of hypothyroidism with Area under ROC curve is 0.999 , indicating a good marker with high sensitivity (100\%) and high specificity (96.2\%). Pseudocholinesterase is significantly less in cases not on treatment with $\mathrm{F}=78, \mathrm{P}<0.001 * *$, however the cases on treatment are more close to controls with $\mathrm{P}=0.18$.

Sleeba S K et (2013) found that Patients who were newly diagnosed with hypothyroidism had a mean pseudocholinesterase level of $3170.19 \mathrm{U} / \mathrm{I}$. Hypothyroid patients on treatment showed a mean pseudocholinesterase level of 6320.32 U/I. Serum Pseudo cholinesterase showed a negative correlation (-0.374) with TSH in the hypothyroid patients on treatment. Pseudo cholinesterase levels in hypothyroids on treatment are more close to controls with $\mathrm{P}=0.189$. Conclusions: Serum pseudocholinesterase activity is decreased by about $31.6 \%$ in hypothyroidism. Pseudo cholinesterase was found to be a good biochemical marker for detecting new cases of hypothyroidism with a sensitivity of $100 \%$ and specificity of $96.2 \%$. Serum Pseudocholinesterase levels may be used as a biochemical marker for diagnosis and prognosis in hypothyroidism. 


\section{CONCLUSION}

Serum Pseudocholinesterase is helpful as biomarker in screening test for hypothyroidism along with thyroid stimulating hormone.

\section{REFERENCES}

1. Kochupillai N. Clinical endocrinology in India. Current Science. 2000;79:1061-1067.

2. Thompson JC, Whittaker M. Pseudocholinesterase activity in thyroid disease. J. Clin. Path. 1965;18:811

3. Porter WH. Carl AB, Edward RA editors, Tietz Textbook of clinical chemistry. Clinical Toxicology. 3rd edition, Elsevier Health Sciences. 1999;940.

4. Vlaicu R, Popescu E, Popescu TA, Cucuianu M. Serum electrophoretic lipoprotein factors and pseudocholinesterase activity in thyroid disease.Endocrinologie. 1978;16(2):147-51.

5. Sleeba SK, Prasad BNR, Bangera M. Pseudocholinesterase as a biochemical marker in hypothyroidism. Asian J Pharm Clin Res. 2013;16(2):9-20.

6. WHO expert consultation. Appropriate body-mass index for Asian populations and its implications for policy and intervention strategies. The Lancet, 2004; 157-163.

7. Hollander CS. Clinical laboratory observation in cases of $\mathrm{T}_{3}$ toxicosis confirmed by radioimmunoassay. Lancet.1972;1:609-611.

8. Schuurs AHWM and Van Weeman BK. Review Enzyme immunoassay. Clin. Chem. Acta.1977; 81:1

9. Uotila M, Ruoslahti E and Engvall E. J. Immunol. Methods. 1981;42:11-15.

10. Charles h. Sawyer and John W. Everett. Liver synthesis of serum cholinesterase. Am j physiol. 1947;148 (3):67583.

11. Allian CC, Poon LS, Chan CSG, Richmond W and Fu $P$ : Enzymatic determination of total serum cholesterol. Clin. Chem 1974; 20: 470.

12. Thompson J.C and Whittakker M. Pseudocholinesterase activity in thyroid disease. J. clin. Path, 1965; 18,811 .

How to Cite this article: Kaushik GG, Soni Reena. Pseudocholinesterase as a predictor marker in hypothyroid patients. Int. j. clin. biomed. res. 2018;4(3): 27-29. 